\title{
Influence of Khat Extract (Catha edulis) on Corrosion Resistance of Co-Cr Dental Alloys
}

Influência do extrato de Khat (Catha edulis) na resistência à corrosão de ligas dentais Co-Cr

\author{
Rassam AL-SUBARI ${ }^{1}$, Nadia MERZOUK ${ }^{2}$, Nasser KABAK ${ }^{1}$, Abdullah GUENBOUR ${ }^{3}$, Sadeq Ali AL-MAWERI ${ }^{4}$, Mohammed Nasser ALHAJJ ${ }^{5}$ \\ 1 - Department of prosthodontic, Faculty of Dentistry, International University for Science and Technology, Syria. \\ 2 - Department of prosthodontic, Faculty of Dentistry, University Mohammed V, Rabat, Morocco. \\ 3 - Laboratory of corrosion and electrochimie, Faculty of Sciences, University Mohammed V, Rabat, Morocco. \\ 4 - Department of Oral Medicine and Diagnostic Sciences, AlFarabi Colleges for Dentistry and Nursing, Riyadh, Saudi Arabia; Department \\ of Oral Medicine, Oral Pathology and Oral Radiology, Faculty of Dentistry, Sana'a University, Yemen. \\ 5 - Department of Prosthodontics, Faculty of Dentistry, Thamar University, Dhamar, Yemen.
}

\begin{abstract}
Objective: The aim of this experimental study was to assess the effect of khat extract with different concentrations on the corrosion resistance of cobalt-chromium (Co-Cr) dental alloys used for removable denture. Material and Methods: The corrosion resistance of three Co-Cr alloys (Neobond II ${ }^{\circledR}$, Kera $501^{\circledR}$ and PD Casta $\mathrm{H}^{\circledR}$ ) was evaluated in artificial saliva in presence of three different concentrations of khat extracts. Fusayama-Meyer artificial saliva was used as a reference solution. The corrosion properties of the alloys were analyzed using potentiodynamic polarization, electrochemical impedance spectroscopy and surface analysis. The data was presented in means, standard deviations, and related figures. Comparison between the different concentrations was done using 1-way ANOVA test. The surface analysis was performed using scanning electron microscopy (SEM). Results: the results showed that the corrosion resistance of the three alloys tested (Neobond $\mathrm{II}^{\circledR}$, Kera $501^{\circledR}$ and PD Casta $\mathrm{H}^{\circledR}$ ) decreased in artificial saliva containing khat extract compared with that of the reference solution. Additionally, the corrosion resistance of the three Co-Cr dental alloys decreased by increasing the concentration of khat extract. Furthermore, the results indicate that Neobond $\mathrm{II}^{\circledR}$ alloy showed the least corrosion resistance compared with that of Kera $501^{\circledR}$ and PD Casta $\mathrm{H}^{\circledR}$ alloys. Conclusion: Khat extract with different concentrations had negative impact on the corrosion resistance of Cr-Co alloys. More in-vivo studies are highly recommended to confirm the results of the present study.
\end{abstract}

\section{KEYWORDS}

Khat; Catha edulis; Partial denture; Corrosion resistance.

\section{RESUIMO}

Objetivo: O objetivo deste estudo experimental foi avaliar o efeito do extrato de khat em diferentes concentrações na resistência à corrosão de ligas dentárias de cobalto-cromo (CoCr) utilizadas em próteses removíveis. Material e Métodos: A resistência à corrosão de três ligas de Co-Cr (Neobond II ${ }^{\circledR}$, Kera $501^{\circledR}$ e PD Casta $\mathrm{H}^{\circledR}$ ) foi avaliada em saliva artificial na presença de três concentrações diferentes de extratos khat. A saliva artificial de Fusayama-Meyer foi usada como solução de referência. As propriedades de corrosão das ligas foram analisadas usando polarização potenciodinâmica, espectroscopia de impedância eletroquímica e análise de superfície. Os dados foram apresentados em médias, desvios-padrão e figuras relacionadas. A comparação entre as diferentes concentrações foi feita usando o teste One-way ANOVA. A análise de superfície foi realizada em microscopia eletrônica de varredura (MEV). Resultados: os resultados mostraram que a resistência à corrosão das três ligas testadas (Neobond $\mathrm{II}^{\circledR}$, Kera $501^{\circledR}$ e PD Casta $\mathrm{H}^{\circledR}$ ) diminuiu na saliva artificial contendo extrato khat em comparação com a solução de referência. Além disso, a resistência à corrosão das três ligas dentais Co-Cr diminuiu com o aumento da concentração de extrato de khat. Além disso, os resultados indicam que a liga Neobond $\mathrm{II}^{\circledR}$ apresentou a menor resistência à corrosão em comparação com as ligas Kera $501{ }^{\circledR}$ e PD Casta $\mathrm{H}^{\circledR}$. Conclusão: $\mathrm{O}$ extrato de Khat com diferentes concentrações teve impacto negativo na resistência à corrosão de ligas de CrCo. Mais estudos in vivo são altamente recomendados para confirmar os resultados do presente estudo.

\section{PALAVRAS-CHAVE}

Khat; Catha edulis; Prótese parcial; Resistência à corrosão. 


\section{INTRODUCTION}

$\mathrm{K}$ hat (Catha edulis) is an evergreen shrub grown in South Arabia (mainly Yemen and South Saudi Arabia) and some East African countries such as Ethiopia, Somalia, Djibouti and Kenya [1,2]. Millions of people in these countries as well as in Europe and North America chew khat on daily basis for its stimulating effects [1$3]$. Khat chewing is practiced as a regular daily habit (particularly in Yemen and some East African countries) and forms a basis of social interaction $[1,2,4]$. The habit involves inserting khat leaves into the mouth, chewing them and keeping the bolus in the buccal fold for several hours [3]. The main chemical components of Khat leaves are alkaloids, mainly cathine and cathinone, amphetamine-like sympathomimetic substances [3]. Other chemical components include amino acides, tannins, fluoride, and traces of vitamins [4,5]. Long term khat chewing has been linked with several systemic and oral complications [3]. Reported oral and dental effects of khat chewing include, periodontal diseases, dental attrition, mucosal white lesions, xerostomia, temporomandibular joint disorders, among others [6-11]. In addition to its effects on oral soft and hard tissues, Khat chewing has been reported to have negative effects on dental restorations and prostheses [12-14]. A 2017 cross-sectional survey investigated the pattern of restorative failure among khat chewers and shammah users in Jazan, Saudi Arabia, and found significant association between khat chewing and various restorative failures in amalgam, composite, crowns and removable prostheses [14]. A more recent experimental study reported that khat extract was associated with the highest effects on the color stability of different types of composite Resins compared to other tested materials [15]. Additionally, one study investigating the influence of khat extract on the corrosion of Nickel cobalt alloys found that khat extract accelerates the corrosion of Nickel cobalt alloys [13].
Cobalt-chromium-based alloys (Co-Cr alloy) are widely used for the fabrication of removable partial dentures and metal ceramic prostheses [16]. Co-Cr alloy exhibits high strength, good cytocompatebility and are nonmagnetic [17,18]. Additionally, Co-Cr alloys have also been found to be more resistant to corrosion than Ni-Cr alloys [16,18]. These properties make Co-Cr ideal alloys to be used in the oral cavity [16]. Given the nature of khat chewing, and the fact that khat leaves are kept in the oral mucobuccal fold for several hours, khat quid and juice usually comes in contact with dental prosthesis, leading to dissolution of these materials. The prolonged contact may have a negative effect on dental alloys including Co-Cr alloys, and as stated above, khat was found to induce corrosion of Ni-Cr alloy. Unfortunately, the literature is scarce regarding the potential effects of khat on dental materials, and so far no studies have investigated the influence of khat (Catha edulis) on corrosion resistance of $\mathrm{Co}-\mathrm{Cr}$ dental alloys. Therefore, the present study aimed to assess the influence of methanolic extract of khat with different concentrations $(0.5,1$, and $2 \mathrm{~g} / \mathrm{L}$ ) on corrosion resistance of $\mathrm{Co}-\mathrm{Cr}$ dental alloys used for removable partial dentures electrochemically and under the scanning electron microscope (SEM). It was hypothesized that Khat extract with different concentrations has no effect on Co-Cr dental alloys in terms of corrosion resistance.

\section{MATERIAL AND METHODS}

\section{Co-Cr Dental Alloys}

Three Co-Cr dental alloys used for removable partial dentures (Neobond $\mathrm{II}^{\circledR}$, Kera $501^{\circledR}$ and PD Casta $\mathrm{H}^{\circledR}$ alloys) were used as test materials in this study. The chemical composition of these alloys is shown in table I. Form each type, two samples were fabricated. For electrochemical measurements, the working electrodes were cylindrically shaped $(7 \mathrm{~mm}$ in 
diameter and $15 \mathrm{~mm}$ length) and covered with a polytetrafluoroethylene (PTFE) coating. The area exposed to the solution was $0.38 \mathrm{~cm}^{2}$. The working electrodes were mechanically polished with abrasive paper of different grades (4001000-1500), washed in distilled water and then dried with ethanol before corrosion test.

Table I - The chemical composition of materials

\begin{tabular}{|c|c|}
\hline Material & Composition (wt \%) \\
\hline Neobond $\|^{\circledR}$ & $\begin{array}{c}\text { Co: } 52.2 \%, \text { Cr: } 27.8 \%, \text { Ga: } 2.5 \%, \text { Fe: } 0.5 \%, \text { Si: } 0.5 \%, \text { C: } 0.4 \% \text {, Divers: } \\
12.4 \%\end{array}$ \\
\hline Kera $501^{\circledR}$ & $\begin{array}{c}\text { Co: } 61 \%, \text { Cr: } 30.25 \%, \text { Mo: } 5.5 \%, \text { Mn: } 0.25 \%, \text { Al: }<0.4 \%, \text { Si: } 0.4 \% \text {, Fe: } \\
\text { 0.5\%, Nb: } 1 \%\end{array}$ \\
\hline PD Casta $H^{\circledR}$ & Co:60\%,Cr:29\%, Mo:6.2\%, Ni: 2\%, Fe: 2\%, C, Si, Mn:< $1 \%$ \\
\hline
\end{tabular}

\section{Khat Extracts}

Fresh khat leaves were collected in summer, weighed, washed with distilled water three times and left to dry for three days in a clean dry room $\left(20 \pm 5^{\circ} \mathrm{C}\right)$ protected from sunlight. After drying, the plant was weighed, packed in a closed foil packet and stored at $20^{\circ} \mathrm{C}$ until use.

Khat was extracted from leaves as described by previous studies [19, 20]. Briefly, dried khat leaves (100 g) were chopped into small pieces, homogenized in $100 \mathrm{~mL}$ of $95 \%$ ethanol, centrifuged at $5000 \mathrm{rpm}$ for $5 \mathrm{~min}$ and the supernatant then filtered with Whatman filter paper (no. 1). Ethanol (100 mL) was added to the remaining leaves and the procedure repeated. The ethanol khat extract was concentrated using a rotary evaporator (BUCHI 461 Water Bath, Switzerland) at $30{ }^{\circ} \mathrm{C}$ with a rotation speed of $70 \mathrm{rpm}$ until $70 \%$ of the ethanol solvent had evaporated. The resulting viscous solution was diluted with $100 \mathrm{~mL}$ of distilled water and then stirred at $1000 \mathrm{rpm}$ with for $1 \mathrm{~h}$ at ambient temperature. The filtrate was kept frozen at $-70{ }^{\circ} \mathrm{C}$ for $24 \mathrm{~h}$ and then dried by lyophilization (CHRIST, Alpha, 2-4 LD Plus). Typically, $100 \mathrm{~g}$ of dried leaves yielded $7 \mathrm{~g}$ of khat extract powder.

\section{Test solution}

The reference electrolyte was FusayamaMeyer artificial saliva [21, 22]. The composition of this solution, which closely resembles natural saliva is: $\mathrm{KCl}(0.4 \mathrm{~g} / \mathrm{l}), \mathrm{NaCl}(0.4 \mathrm{~g} / \mathrm{l})$, $\mathrm{CaCl}_{2} \cdot 2 \mathrm{H}_{2} \mathrm{O}(0.906 \mathrm{~g} / \mathrm{l}), \mathrm{NaH}_{2} \mathrm{PO} 4.2 \mathrm{H}_{2} \mathrm{O}(0.690$ $\mathrm{g} / \mathrm{l}), \mathrm{Na}_{2} \mathrm{~S} .9 \mathrm{H}_{2} \mathrm{O}(0.005 \mathrm{~g} / \mathrm{l})$, Urea $(1 \mathrm{~g} / \mathrm{l})$. The $\mathrm{pH}$ was measured with a glass electrode $(\mathrm{pH}$ meter HANNA Instrument, France). The $\mathrm{pH}$ of this reference solution measured was 5.3. The second medium used had the same contents as the reference solution but enriched with khat extract with a concentration $0.5 \mathrm{~g} / \mathrm{l}$. The $\mathrm{pH}$ measured was 4.6. The third medium was identical to the reference solution but enriched with khat extract with a concentration $1 \mathrm{~g} / \mathrm{l}$. The $\mathrm{pH}$ measured was 4.5. The last medium used had the same contents as the reference solution but enriched with khat extract with a concentration 2 $\mathrm{g} / \mathrm{l}$. The $\mathrm{pH}$ measured was 4.5 .

\section{Electrochemical measurements}

Potentiodynamic measurements and electrochemical impedance spectroscopy (EIS) were performed using a potentiostat (Voltalab® PGZ 301 radiometer analytical, France). The analyses were carried out in a three-electrode cell, using a saturated calomel electrode as reference electrode, platinum as counter-electrode and Co-Cr samples was used as working electrode, controlled by corrosion analysis software model (Voltamaster 4). The measurements were performed after the establishment of a reasonable steady state condition, which was safely achieved after 30 min of immersion. The polarization curves were plotted in the potential range of $-1000 \mathrm{mV} /$ SCE to $+1000 \mathrm{mV} / \mathrm{SCE}$ at scanning rate of 0.2 $\mathrm{mV} / \mathrm{s}$. The EIS measurements were carried out in the frequency range of $100 \mathrm{kHz}$ to $0.01 \mathrm{~Hz}$ at the open circuit potential, after $30 \mathrm{~min}$ of immersion, by applying a superimposed potential variation with $10 \mathrm{mV}$ amplitude. The corrosion parameters are: corrosion potential $\left(\mathrm{E}_{\mathrm{corr}}\right)$, corrosion current density $\left(\mathrm{I}_{\text {corr }}\right)$, polarization resistance $\left(\mathrm{R}_{\mathrm{p}}\right)$, charge 
transfer resistance $\left(\mathrm{R}_{\mathrm{ct}}\right)$, resistance of solution $\left(R_{s}\right)$ and double layer capacitance $\left(\mathrm{C}_{\mathrm{dl}}\right)$ [23]. The values of the corrosion parameters are the mean of two experiments with a maximum error of 10 $15 \%$.

\section{Surface analysis}

Two specimens of each material were observed using scanning electron microscopy (SEM) (Philips, Quanta 200 X. TM-C) Fei Company). One specimen of each material was subjected to immersion for 15 day in artificial saliva containing khat extract (Catha edulis) and compared to analysis of initial state materials.

\section{Statistical analysis}

The software program SPSS V25 for Windows was used for data analysis. The data was presented in means, standard deviations, and related figures. Comparison between the different concentrations was done using 1-way ANOVA test. A P-value $<0.05$ was considered significant.

\section{RESULTS}

\section{Polarization curves}

The polarization curves of the three alloys (Neobond $\mathrm{II}^{\circledR}$, Kera $501^{\circledR}$ and PD Casta $\mathrm{H}^{\circledR}$ ) in artificial saliva in the absence and presence of different concentrations of khat extracts are shown in Figure 1 (A-c). It can be observed that the corrosion current densities of the three alloys increased by increasing concentrations of khat extract. At artificial saliva containing khat extract with a concentration $2 \mathrm{~g} / \mathrm{l}$, Kera $501^{\circledR}$ showed an active dissolution peak at - 0.1V (SCE) and a high passive current density. Conversely, the polarization resistance of the three alloys decreased by increasing concentrations of khat extract.
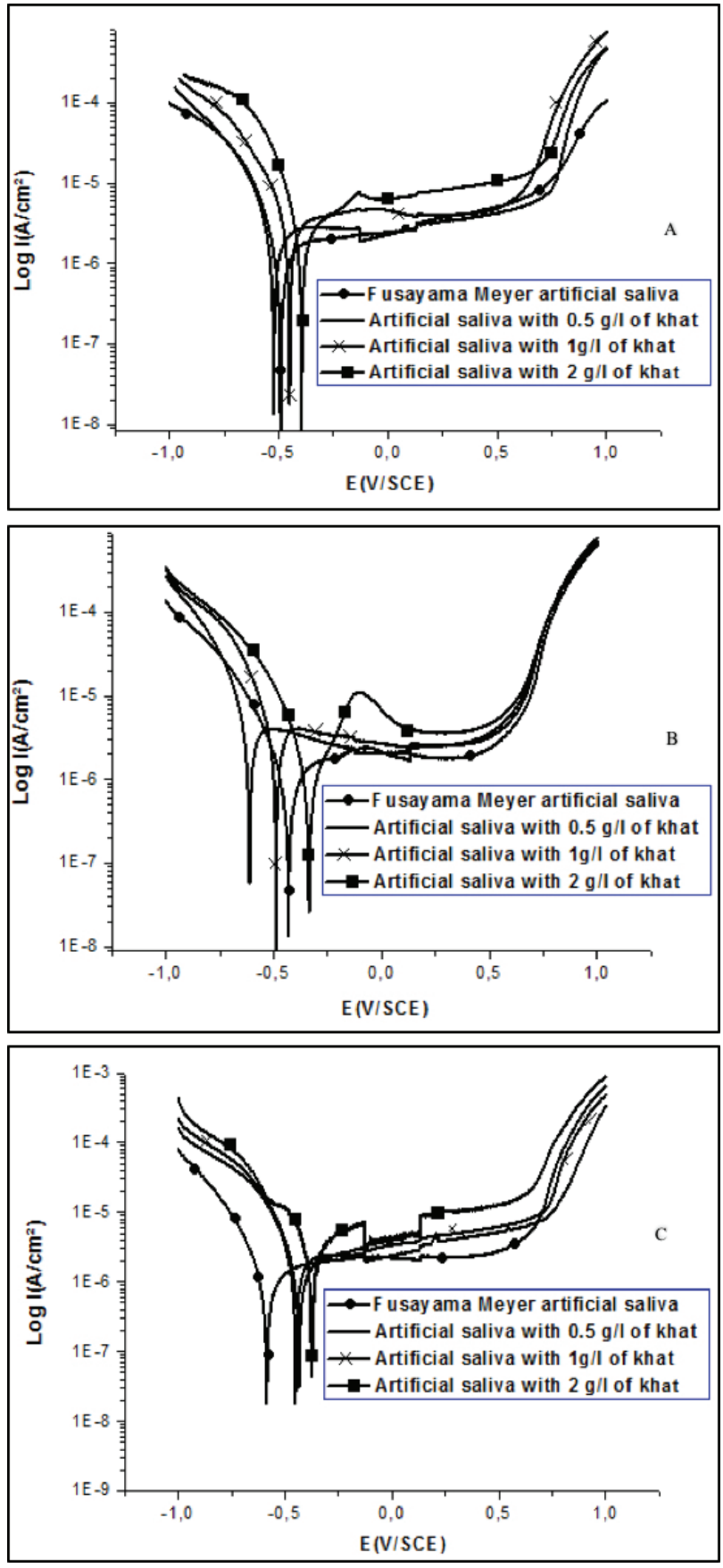

Figure 1- The polarization curves of Neobond $\|^{\circledR}$ alloy (A), Kera $501^{\circledR}$ alloy (B), and PD Casta $\mathrm{H}^{\circledR}$ alloy (C) in artificial saliva in the absence and presence of different concentrations of khat extracts.

Similar polarization curves were obtained for both Kera $501{ }^{\circledR}$ and PD Casta $\mathrm{H}^{\circledR}$ alloys in Fusayama-Meyer artificial saliva, and the polarization resistance values obtained for Kera $501^{\circledR}$ and PD Casta $\mathrm{H}^{\circledR}$ alloys were also of the 
same order. The corrosion current densities obtained for Neobond $\mathrm{II}^{\circledR}$ alloy in FusayamaMeyer artificial saliva was high compared with that of Kera $501^{\circledR}$ and PD Casta $\mathrm{H}^{\circledR}$ alloys. More details are presented in Table II.

Table II - Corrosion parameters of the three dental alloys (Neobond $\|^{\circledR}$, Kera $501^{\circledR}$ and PD Casta $\mathrm{H}^{\circledR}$ ) obtained from potentiodynamic polarization in artificial saliva in the absence and presence of different concentrations of khat extract

\begin{tabular}{|c|c|c|c|}
\hline & $\begin{array}{c}E_{\text {corr }} \\
\text { (mV/SCE) }\end{array}$ & $\begin{array}{c}\text { Icorr } \\
\left(\mu \mathrm{Acm}^{-2}\right)\end{array}$ & $\begin{array}{c}R_{p} \\
\left(k \Omega \mathrm{cm}^{2}\right)\end{array}$ \\
\hline \multicolumn{4}{|l|}{ Neobond III ${ }^{\circledR}$} \\
\hline Fusayama-Meyer artificial saliva & $-485.0 \pm 8.7$ & $5.6 \pm 0.3$ & $12.2 \pm 0.5$ \\
\hline Saliva with $0.5 \mathrm{~g} / \mathrm{l}$ of khat extract & $-521.0 \pm 6.5$ & $10.5 \pm 0.4$ & $7.6 \pm 0.4$ \\
\hline Saliva with $1 \mathrm{~g} / \mathrm{l}$ of khat extract & $-406.0 \pm 8.0$ & $13.8 \pm 0.6$ & $5.4 \pm 0.3$ \\
\hline Saliva with $2 \mathrm{~g} / \mathrm{l}$ of khat extract & $-446.5 \pm 8.3$ & $16.8 \pm 0.5$ & $3.6 \pm 0.4$ \\
\hline ANOVA test & $P=0.001$ & $P<0.001$ & $P<0.001$ \\
\hline \multicolumn{4}{|l|}{ Kera $501^{\circledR}$} \\
\hline Fusayama-Meyer artificial saliva & $-458.4 \pm 21.9$ & $2.0 \pm 0.2$ & $14.2 \pm 0.3$ \\
\hline Saliva with $0.5 \mathrm{~g} / \mathrm{l}$ of khat extract & $-593.7 \pm 23.5$ & $9.9 \pm 0.3$ & $9.1 \pm 0.3$ \\
\hline Saliva with $1 \mathrm{~g} / \mathrm{l}$ of khat extract & $-507.9 \pm 14.6$ & $12.4 \pm 0.5$ & $6.3 \pm 0.2$ \\
\hline Saliva with $2 \mathrm{~g} / \mathrm{l}$ of khat extract & $-354.8 \pm 13.8$ & $15.8 \pm 0.4$ & $3.9 \pm 0.2$ \\
\hline ANOVA test & $P=0.001$ & $P<0.001$ & $P<0.001$ \\
\hline \multicolumn{4}{|l|}{ PDCasta $\mathrm{H}^{\circledR}$} \\
\hline Fusayama-Meyer artificial saliva & $-541.6 \pm 18.7$ & $1.8 \pm 0.2$ & $14.8 \pm 0.6$ \\
\hline Saliva with $0.5 \mathrm{~g} / \mathrm{l}$ of khat extract & $-467.0 \pm 12.5$ & $8.0 \pm 0.9$ & $9.3 \pm 0.2$ \\
\hline Saliva with $1 \mathrm{~g} / \mathrm{l}$ of khat extract & $-447.4 \pm 9.8$ & $11.4 \pm 0.3$ & $7.1 \pm 0.2$ \\
\hline Saliva with $2 \mathrm{~g} / \mathrm{l}$ of khat extract & $-381.0 \pm 4.0$ & $14.9 \pm 0.7$ & $4.3 \pm 0.1$ \\
\hline ANOVA test & $P=0.001$ & $P<0.001$ & $P<0.001$ \\
\hline
\end{tabular}

\section{Electrochemical impedance spectroscopy}

Figure 2 (A-C) shows the the Nyquist diagrams of Neobond $\mathrm{II}^{\circledR}$, Kera $501^{\circledR}$ and PD Casta $\mathrm{H}^{\circledR}$ alloys in artificial saliva in the absence and presence of different concentrations of khat extracts. The plots of the three alloys are open semicircle and the diameter of the open semicircle decreases by increasing the concentration of khat extract. Diagrams can be represented by an equivalent circuit consisting of a double layer capacitance and charge transfer resistance in parallel (Figure 3). The values of charge transfer $\left(\mathrm{R}_{\mathrm{ct}}\right)$, double layer capacitance $\left(\mathrm{C}_{\mathrm{dl}}\right)$ and solution resistance $\left(\mathrm{R}_{\text {sol }}\right)$ of Neobond $\mathrm{II}{ }^{\circledR}$, Kera $501^{\circledR}$ and PD Casta $\mathrm{H}^{\circledR}$ alloys are reported in Table III. From the results of Nyquist diagrams, the Neobond $\mathrm{II}^{\circledR}$, Kera $501^{\circledR}$ and PD Casta $\mathrm{H}^{\circledR}$ alloys showed low charge transfer resistance in artificial saliva containing different concentrations of khat extracts compared with that of reference solution. Additionally, the charge-transfer resistance $\left(\mathrm{R}_{\mathrm{ct}}\right)$ decreases by increasing the concentration of khat extract. In Fusayama-Meyer artificial saliva, the Neobond $\mathrm{II}^{\circledR}$ alloy has low charge transfer resistance compared with that of Kera $501^{\circledR}$ and PD Casta $\mathrm{H}^{\circledR}$ alloys. The values of double layer capacitance $\left(\mathrm{C}_{\mathrm{dl}}\right)$ of the Neobond II ${ }^{\circledR}$, Kera $501^{\circledR}$ and PD Casta $\mathrm{H}^{\circledR}$ alloys increases by increasing concentration of khat extract compared with that of reference solution.
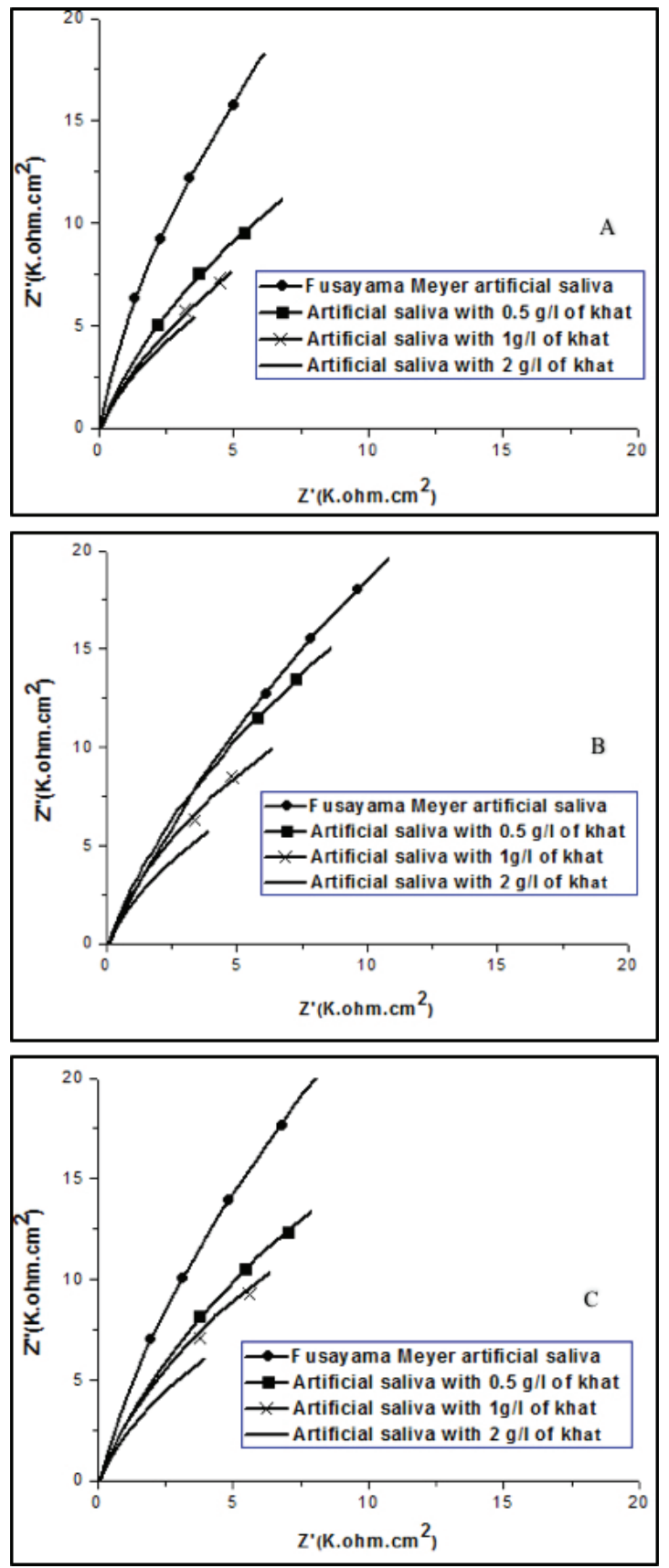

Figure 2 - Nyquist complex impedance plot for Neobond $\|^{\circledR}$ alloy (A), Kera 501 alloy (B), PD Casta $\mathrm{H}^{\circledR}$ alloy (C) in artificial saliva in the absence and presence of different concentrations of khat extracts. 


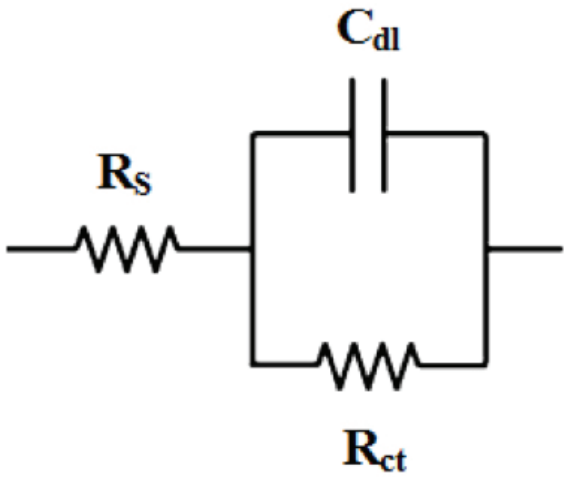

Figure 3 - Equivalent circuit, where $R_{s}$ is the solution resistance, $R_{c t}$ the charge transfer resistance and Cdl the double layer capacitance.

Table III - Corrosion parameters of the three alloys obtained from impedance measurements in artificial saliva in the absence and presence of different concentrations of khat extracts

\begin{tabular}{|c|c|c|c|}
\hline & $\begin{array}{c}\text { Rsol } \\
\left(\Omega \mathrm{cm}^{2}\right)\end{array}$ & $\begin{array}{c}\text { Rct } \\
\left(\mathrm{k} \Omega \mathrm{cm}^{2}\right)\end{array}$ & $\begin{array}{c}\text { Cdl } \\
\left(\mu \mathrm{F} \mathrm{cm}^{-2}\right)\end{array}$ \\
\hline \multicolumn{4}{|l|}{ Neobond III } \\
\hline Fusayama-Meyer artificial saliva & $79.3 \pm 1.1$ & $120.1 \pm 1.4$ & $13.0 \pm 0.4$ \\
\hline Saliva with $0.5 \mathrm{~g} / \mathrm{l}$ of khat extract & $75.4 \pm 1.3$ & $48.7 \pm 1.5$ & $22.8 \pm 0.5$ \\
\hline Saliva with $1 \mathrm{~g} / \mathrm{l}$ of khat extract & $73.5 \pm 1.3$ & $32.1 \pm 1.5$ & $33.5 \pm 0.7$ \\
\hline Saliva with $2 \mathrm{~g} / \mathrm{l}$ of khat extract & $75.3 \pm 1.0$ & $23.5 \pm 1.0$ & $47.8 \pm 0.5$ \\
\hline ANOVA test & $P=0.033$ & $P<0.001$ & $P<0.001$ \\
\hline \multicolumn{4}{|l|}{ Kera $501^{\circledR}$} \\
\hline Fusayama-Meyer artificial saliva & $76.3 \pm 2.1$ & $137.2 \pm 0.9$ & $11.8 \pm 0.3$ \\
\hline Saliva with $0.5 \mathrm{~g} / \mathrm{l}$ of khat extract & $72.4 \pm 1.3$ & $68.1 \pm 1.1$ & $22.1 \pm 0.8$ \\
\hline Saliva with $1 \mathrm{~g} / \mathrm{l}$ of khat extract & $69.3 \pm 1.0$ & $41.6 \pm 1.4$ & $31.9 \pm 1.3$ \\
\hline Saliva with $2 \mathrm{~g} / \mathrm{l}$ of khat extract & $67.3 \pm 0.9$ & $25.0 \pm 1.8$ & $44.5 \pm 1.1$ \\
\hline ANOVA test & $\mathrm{P}=0.011$ & $P<0.001$ & $P<0.001$ \\
\hline \multicolumn{4}{|l|}{ PDCasta ${ }^{\circledR}$} \\
\hline Fusayama-Meyer artificial saliva & $140.8 \pm 1.4$ & $156.9 \pm 1.4$ & $9.9 \pm 0.8$ \\
\hline Saliva with $0.5 \mathrm{~g} / \mathrm{l}$ of khat extract & $78.1 \pm 2.2$ & $67.5 \pm 2.7$ & $22.6 \pm 2.0$ \\
\hline Saliva with $1 \mathrm{~g} / \mathrm{l}$ of khat extract & $69.6 \pm 0.4$ & $44.5 \pm 0.6$ & $34.5 \pm 1.7$ \\
\hline Saliva with $2 \mathrm{~g} / \mathrm{l}$ of khat extract & $66.7 \pm 1.6$ & $28.2 \pm 1.1$ & $43.5 \pm 1.3$ \\
\hline ANOVA test & $P<0.001$ & $P<0.001$ & $P<0.001$ \\
\hline
\end{tabular}

\section{Surface analysis}

Scanning electron microscopy (SEM) was used to analyze the surface of the Neobond $\mathrm{II}^{\circledR}$, Kera $501^{\circledR}$ and PD Casta $\mathrm{H}^{\circledR}$ after immersion in artificial saliva containing khat extract for 15 days and compared to analysis of initial state materials. In the case Neobond $\mathrm{II}^{\circledR}$, the comparison of SEM photomicrographs (Figure $4 \mathrm{~A}$ and $4 \mathrm{~B}$ ) showed a uniform corrosion, which covered the surface of the alloy after immersion in artificial saliva containing khat extract. In the case Kera $501{ }^{\circledR}$, the comparison of SEM photomicrographs (Figure 5A and 5B) showed a pitting corrosion on the surface after immersion in artificial saliva containing khat extract. In the case PD Casta $\mathrm{H}^{\circledR}$, the comparison of SEM photomicrographs (Figure 6A and 6B) showed slight localized corrosion after immersion in artificial saliva containing khat extract.

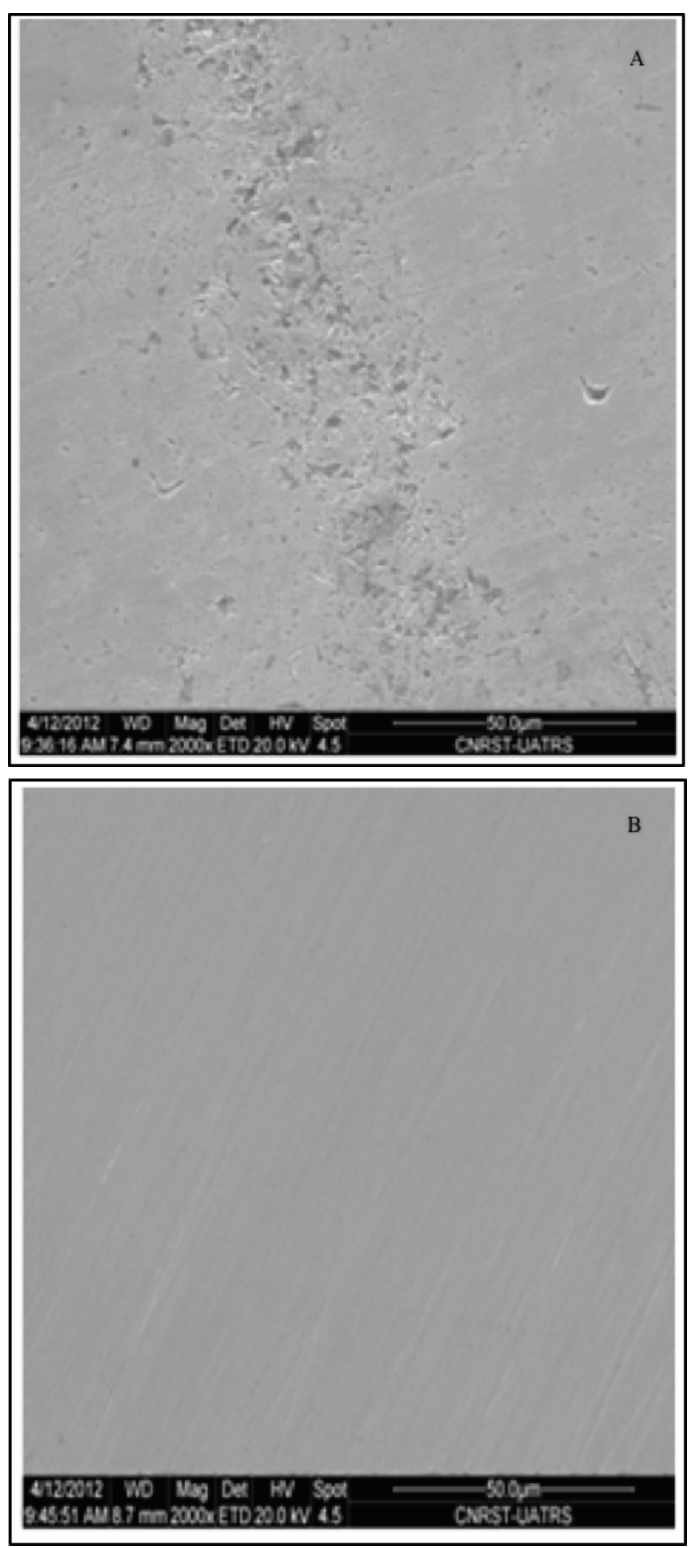

Figure 4 - The scanning electron microscopy of Neobond $\|^{\circledR}$ in artificial saliva containing khat extract $(A)$ and in initial state (B). 

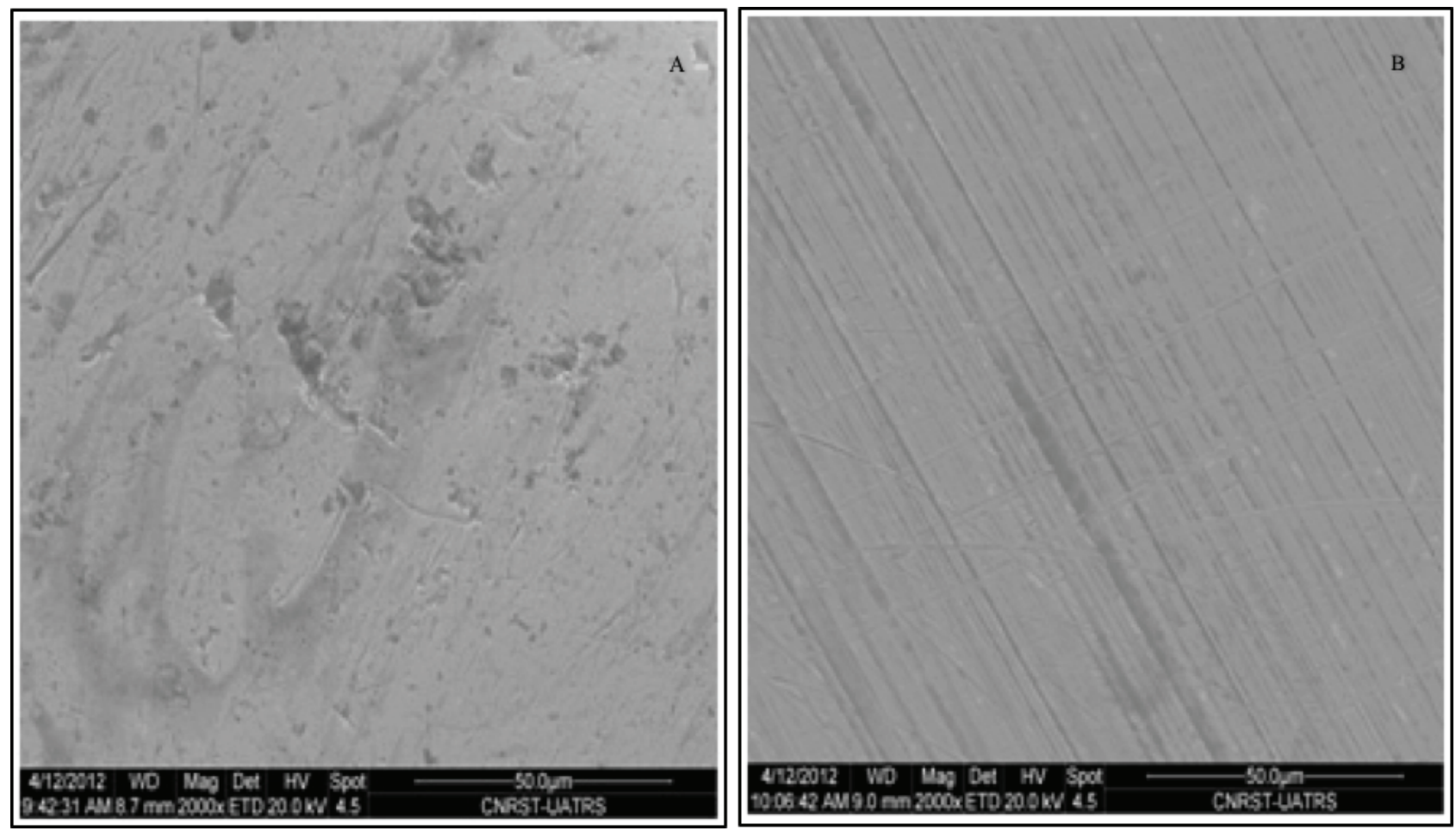

Figure 5 - The scanning electron microscopy of Kera $501^{\circledR}$ in artificial saliva containing khat extract (A) and in initial state (B).
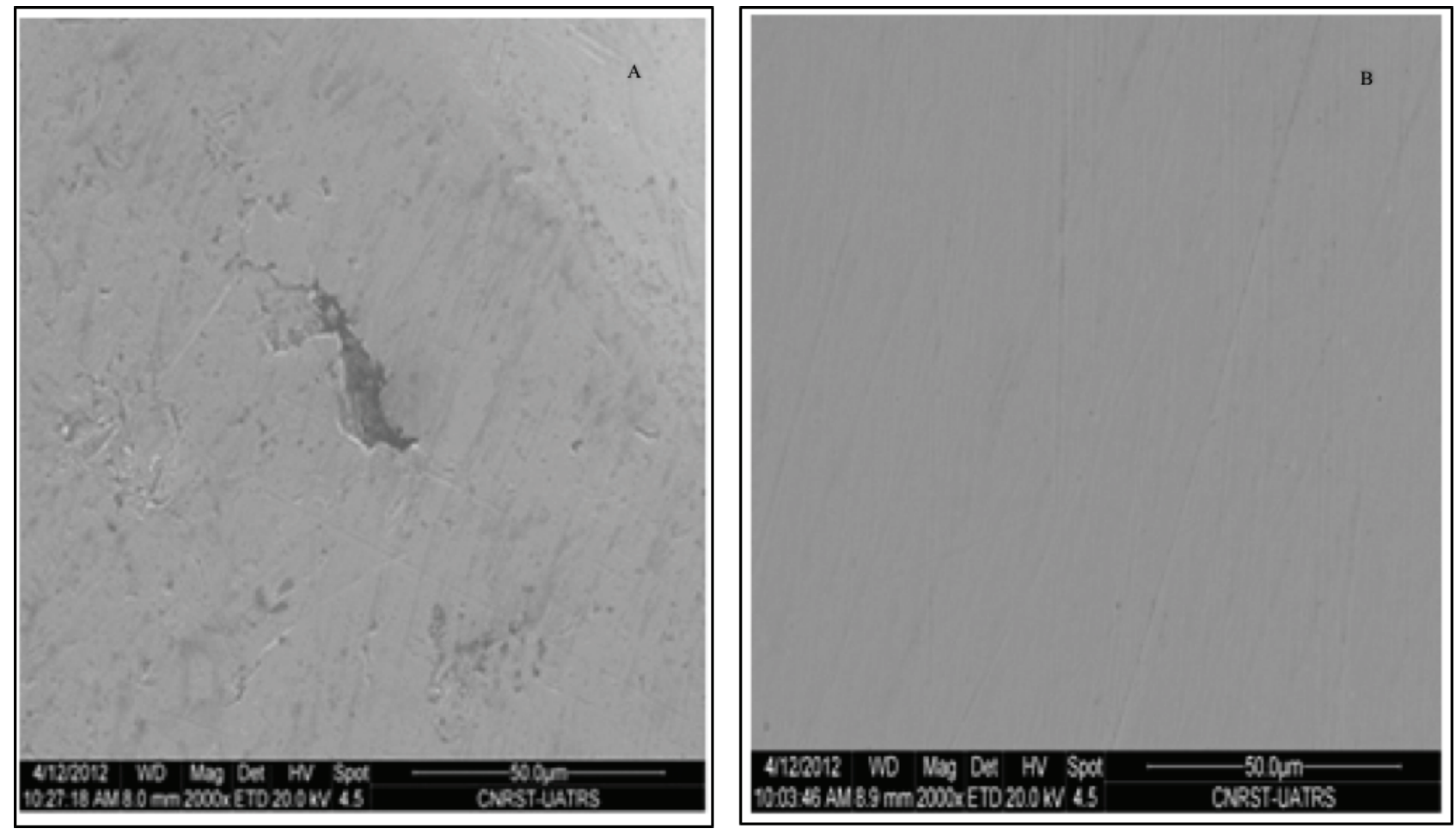

Figure 6 - The scanning electron microscopy of $\mathrm{PD}$ Casta $\mathrm{H}^{\circledR}$ in artificial saliva containing khat extract $(\mathrm{A})$ and in initial state (B). 


\section{DISCUSSION}

Khat chewing is a widespread social habit in some parts of the world. This habit has been reported to have several detrimental effects on oral and dental tissues [8,9,23,24]. There is an extensive literature on khat-related oral conditions [6-9,12,23,24]. However, the literature is scarce regarding the potential effects of khat on dental prosthesis and restorations. Hence, the present study investigated the effects of Khat extract on the corrosion behavior of Co-Cr dental alloy used for removable partial dentures. To the best of our knowledge, this is the first study that evaluated the effects of khat on the corrosion resistance of Co-Cr dental alloys. Overall, the results of the present study showed that the corrosion resistance of the three alloys tested (Neobond $\mathrm{II}^{\circledR}$, Kera $501^{\circledR}$ and PD Casta $\mathrm{H}^{\circledR}$ ) decreased in artificial saliva containing khat extract compared with that of reference solution. Additionally, the corrosion resistance of the three Co-Cr dental alloys decreased by increasing concentration of khat extract. Furthermore, the results indicate that Neobond $\mathrm{II}^{\circledR}$ alloy which contain no Mo show least corrosion resistance compared with that of Kera $501^{\circledR}$ and PD Casta $\mathrm{H}^{\circledR}$ alloys.

Khat leaves contain a complex group of alkaloids namely, phenylalkylamines, phenylpentylamines, and cathedulins [3]. Khat also contains amino acids, tannins, vitamins and minerals (Calcium, Manganese, Iron, Zinc and Fluoride) $[3,5,25]$. Chemicals components of khat, particularly fluoride may have a critical role in corrosion of metallic materials [5]. Khat chewing involves chewing fresh khat leaves and storing the bolus inside the mouth for several hours. As a result, the chemical substances of khat usually dissolve in the saliva and may affect the metallic materials and prosthesis [15]. Altabachew et al. [5] assessed the Fluoride content of Ethiopian khat (Catha edulis) chewing leaves; and found that the fluoride concentration was $12 \mu \mathrm{g} \mathrm{g}-1$ in matured leaves and $6.5 \mu \mathrm{g} \mathrm{g}-1$ in young leaves [5]. Interestingly, Ameer et al [26] showed that in artificial saliva containing different concentration of fluoride, the corrosion rate of $\mathrm{Co}-\mathrm{Cr}$ and $\mathrm{Ni}-\mathrm{Cr}$ dental alloys increased by increasing concentration of fluoride. In line with that, Prioteasa et al [27] showed that by adding of fluoride ions to Fusayama-Meyer artificial saliva, the corrosion resistance of $\mathrm{Co}-\mathrm{Cr}$ and $\mathrm{Ni}-\mathrm{Cr}$ dental alloys is diminished. The results of the latter two studies substantiate the theory that fluoride and other chemical components of khat may be responsible for the decrease in corrosion resistance of $\mathrm{Co}-\mathrm{Cr}$ alloys seen in the present study. The prolonged close contact of khat with Co-Cr alloy in khat chewers may lead to accelerated corrosion of Co$\mathrm{Cr}$ alloy, with subsequent release of corrosion products including metal ions. This is very important because corrosion products of dental alloys contain metal ions and may be the reason for allergic and some other diseases reported among khat chewers.

Unsurprisingly, Neobond $\mathrm{II}^{\circledR}$ alloy, which contain no Mo showed the least corrosion resistance compared with that of Kera $501{ }^{\circledR}$ and PD Casta $\mathrm{H}^{\circledR}$ alloys. Geis-Gerstorfer et al [28] showed that alloys, which contain no Mo are known to be susceptible to pitting corrosion. On the other hand, Kera $501^{\circledR}$ and PD Casta $\mathrm{H}^{\circledR}$ alloys, which contain a high Co content (61 wt. \%, 60 wt. \% respectively), showed the best corrosion resistance compared with that of Neobond $\mathrm{II}^{\circledR}$ alloy which contain Co content (52.2 wt. \%). Thus, in Fusayama-Meyer artificial saliva the corrosion resistance of the three Co-Cr dental alloys are in the following order: Kera $501^{\circledR} \approx$ PD Casta $\mathrm{H}^{\circledR}>$ Neobond $\mathrm{II}^{\circledR}$. The results of surface analysis by using the scanning electron microscopy showed corrosion on the surface of Co-Cr alloys after immersion in artificial saliva containing khat extract; such results substantiate the results obtained from potentiodynamic polarization curves and Nyquist impedance diagrams. On the basis of 
the results obtained, khat chewing should be avoided in patients treated with Co-Cr dental alloys. Further in-vitro and in-vivo studies are highly recommended.

\section{CONCLUSION}

The findings of the present study suggest that the Khat (Catha edulis) has a negative effect on the corrosion resistance of Co-Cr alloy. The corrosion resistance of the three Co-Cr alloys decreased in artificial saliva containing khat extract, and the degree of corrosion resistance was associated with the concentration of the khat extract.

\section{Acknowledgements}

The authors gratefully acknowledge the support from Faculty of Dentistry, Mohammed V University - Souisi, Rabat, Morocco, Faculty of Medicine and Pharmacy, Mohammed V University - Souisi, Rabat, Morocco, Faculty of Sciences, Mohammed V University - Agdal, Rabat, Morocco; National centre for scientific and technical reserche, Rabat, Morocco, and Faculty of Dentistry, International University for Science and Technology, Syria.

\section{REFERENCES}

1. Gebrie A, Alebel A, Zegeye A, Tesfaye B. Prevalence and predictors of khat chewing among Ethiopian university students: a systematic review and meta-analysis. PloS one. 2018;13(4):e0195718.

2. Kassim S. The impact of protective psychosocial factors on khat chewing among male medical and dental future health-care providers in Yemen. J Dent Sci. 2020;15(4):451:6.

3. Al-Habori M. The potential adverse effects of habitual use of Catha edulis (khat). Expert Opin Drug Saf. 2005;4(6):1145-54.

4. Al-MaweriSA, Warnakulasuriya S, Samran. A Khat (Catha edulis) and its oral health effects: an updated review. J Investig Clin Dent. 2018;9(1):e12288.

5. Atlabachew M, Chandravanshi BS, Zewge F, Redi M. Fluoride content of Ethiopian khat (Catha edulis Forsk) chewing leaves. Environ Toxicol Chem. 2011;93(1):32-43

6. Alhaj WA, Alhaji MN. Prevalence of melanin pigmentation in a yemeni population and its relation to some risk factors. Braz Dent Sci. 2020;23(2):9.

7. Almashraqi A, Ahmed EA, Mohamed NS, Al-Maweri SA, Halboub ES. Evaluation of the effects of chronic qat chewing on lateral pterygoid muscle using MRI. Cranio. 2019:1-9. doi: 10.1080/08869634.2019.1703160
8. Almashraqi AA, Ahmed EA, Mohamed NS, Halboub ES. An MRl evaluation of the effects of qat chewing habit on the temporomandibular joint. Oral Surg Oral Med Oral Pathol Oral Radiol. 2018;126(3):272-82.

9. Al-Maweri SA, Alaizari NA, Al-Sufyani GA. Oral mucosal lesions and their association with tobacco use and qat chewing among Yemeni dental patients. J Clin Exp Dent. 2014;6(5):e460-6.

10. Al-Maweri SA, Al-Jamaei A, Saini R, Laronde DM, Sharhan A. White oral mucosal lesions among the Yemeni population and their relation to local oral habits. J Investig Clin Dent. 2018;9(2):e12305.

11. Dhaifullah E, Al-Maweri SA, Al-Motareb F, Halboub E, ElkhatatE, Baroudi K, et al. Periodontal health condition and associated factors among university students, Yemen. J Clin Diagn Res. 2015;9(12):ZC30-3.

12. Al Moaleem MM, Porwal A, Al Ahmari NM, Shariff M, Homeida HE, Khalid A. Khat chewing induces a floral shift in dental material-associated microbiota: a preliminary study. Med Sci Monit. 2020;26:e918219.

13. Al-Anesi WA, Madfa AA, Dubais MA, Albahari AA. Effects of Khat extract and other staining media on color change of composite resins subjected to various polishing methods. Oral Biol Den. 2019;7(1):e9.

14. Sayed M, Bosly R, Hakami H, Mugri M, Bhandi S. Patterns of restorative failure among Khat and Shammah users in Jazan city, kingdom of Saudi Arabia: a cross-sectional survey. J Contemp Dent Pract. 2017;18(3):234-40.

15. Al-Subari R. Corrosion behavior of $\mathrm{Ni}$-Cr dental alloys In artificial saliva with different concentrations Of Khat extracts. Aust J Basic Appl Sci. 2013;7(9):87-96.

16. Galo R, Ribeiro RF, Rodrigues RC, Rocha LA, de Mattos Mda G. Effects of chemical composition on the corrosion of dental alloys. Braz Dent J. 2012;23(2):141-8.

17. Grimaudo NJ. Biocompatibility of nickel and cobalt dental alloys. Gen Dent. 2001;49(5):498-503.

18. Mercieca S, Caligari Conti M, Buhagiar J, Camilleri J. Assessment of corrosion resistance of cast cobalt-and nickel-chromium dental alloys in acidic environments. J Appl Biomater Funct Mater. 2018;16(1):47-54.

19. Aziz HA, Peh KK, Tan YTF. Extraction and microencapsulation of khat: effects on sexual motivation and estradiol level in female rats. J Sex Med. 2009;6(3):682-95.

20. DimbaE, Gjertsen B, Bredholt T, Fossan K, Costea D, Francis G, etal. Khat (Catha edulis)-induced apoptosis is inhibited by antagonists of caspase-1 and-8 in human leukaemia cells. Br J Cancer. 2004;91(9):1726-34.

21. Gal J-Y,Fovet Y,Adib-Yadzi M. About a synthetic saliva for in vitro studies. Talanta. 2001;53(6):1103-15.

22. Huang H-H, Chiu Y-H, Lee T-H, Wu S-C, Yang H-W, Su K-H, et al. Ion release from NiTi orthodontic wires in artificial saliva with various acidities. Biomaterials. 2003;24(20):3585-92.

23. Kalakonda B, Al-Maweri S-A, Al-Shamiri H-M, ljaz A, Gamal S, Dhaifullah E. Is Khat (Catha edulis) chewing a risk factor for periodontal diseases? A systematic review. J Clin Exp Dent. 2017;9(10):e1264-e1270.

24. AL-Maweri SA, AIAkhali M. Oral hygiene and periodontal health status among khat chewers. A case-control study. J Clin Exp Dent. 2017;9(5):e629-e634.

25. Atlabachew M, Chandravanshi BS, Redi M. Concentration levels of essential and non-essential metals in Ethiopian khat (Catha edulis Forsk). Biol Trace Elem Res. 2010;138(1-3):316-25.

26. Ameer M, Khamis E, Al-Motlaq M. Electrochemical behavior of non-precious dental alloys in bleaching agents. Electrochim Acta. 2004;50(1):141-8. 
27. Prioteasa P, lbris N, Visan T. The influence of chemical nature on the corrosion behaviour of some dental alloys in Fusayama-Meyer artificial saliva. J Optoelectron Adv Mater.2007;9(11):3405-10.
28. Geis-Gerstorfer J, Weber H. In vitro corrosion behavior of four NiÅ Cr dental alloys in lactic acid and sodium chloride solutions. Dent Mater. 1987;3(6):28995.

\section{Mohammed Nasser Alhajj}

(Corresponding address)

Department of Prosthodontics, Faculty of Dentistry, Thamar University

Dhamar, Yemen

Date submitted: 2020 May 30

Email:m.n.alhajj@hotmail.com

Accept submission: 2020 0ct 09 